\title{
A Transitivity Analysis of the Arab Revolutions Representations in Western Newspapers: The Washington Post, The Guardian and Le Figaro as Case Studies.
}

\author{
AYMANE EDOUIHRI* \\ Sidi Mohamed Ben Abdellah University Faculty of Letters and Human \\ Sciences, Kingdom of Morocco \\ Aymane5@hotmail.com \\ Dr. YAHYA YACHOUTI \\ Sidi Mohamed Ben Abdellah University Faculty of Letters and Human \\ Sciences, Kingdom of Morocco \\ yechouti@hotmail.com
}

DOI: http://doi.org/10.36892/ijlls.v2i3.344

\begin{tabular}{ll}
$\begin{array}{l}\text { Received: } \\
\text { 01/07/2020 }\end{array}$ & The earthshaking event of the Arab revolutions profoundly impacted \\
\hline Accepted: & international relations and sparked heated discussions and analysis of East \\
$08 / 09 / 2020$ & and West encounters. Such a sizable opportunity creates an interesting \\
& momentum in revisiting western representation of the orient. Such \\
& representation traditionally feeds on colonial discourse's binarism, \\
Keywords: & polarization and othering. Thus, this paper aims at examining western press \\
Newspaper articles; & discourse on the Arab Spring through transitivity analysis. The analysis \\
Representation; & examines the Washington Post, the Guradian and le Figaro's articles written \\
The Arab revolutions; & about the Arab revolutions. Enlightened by Systemic Functional Linguistics, \\
Transitivity analysis. & transitivity analysis unveils the embedded constructs in the process types, \\
& goals and actors deployed by the newspapers'articles writers. Practically, the \\
& data is sampled following a simple random sampling method in order to \\
& obtain an objective and representative sample. Interestingly, the analysis yield \\
& significant findings in terms of processes types and their distribution, roles of \\
the actors and use of the goal.
\end{tabular}

\section{INTRODUCTION}

The Arab Spring, The Arab Awakening, The Arab Revolutions/uprisings are all terms used to describe the earthshaking upheavals sweeping the Arab world since the beginning of the second decade of the twenty-first century. First sparked by a street vendor's selfimmolation in the Tunisian city of Sidi Bouzid, the fast-growing demonstrations against poverty, inflation and unequal distribution of wealth turned into determined calls for liberty, social justice and the downfall of the regime. All the Middle East and North Africa (MENA) region was shaken and the contagion of regime overthrow spread like fire in the harmattan in most of the Arab countries, which resulted in the step down of the Tunisian, Egyptian and Yamani presidents and the killing of Libya's leader. The Arab Spring is seen as people's endeavor to break the shackles of West supported/manipulated regimes in the region towards salvation from ignorance, poverty, inferiority and tyranny (Gelvin, 2015). Ostensibly, it is a historical moment in the Arab world which created an unprecedented momentum for Arabs to revisit problematized issues as identity, nationalism and belongingness. The protestors' thunderous calls for reviving nationalism and common identity are strengthened by and coupled with the adoption of notions of democracy, freedom, gender equality and justice. Undeniably, echoing calls of "liberty, dignity, social justice" from Tahrir Square in Egypt or 
in front of the Tunisian ministry of interior have as well shaken western capitals which seemed astonished by the nature of the unexpected events and the protestors' demands. (Ramadan, 2012)

Uncovering ideologies and representation constructs embedded in text through the processes of transitivity analysis is one of the most significant deconstructive tools of discourse. Halliday's (1978, p 45-46) distinction of the ideational, interpersonal and textual functions of language facilitated the breaking of texts into immediate constituents and the analysis of internal workings of meaning making. One of the mechanisms of meaning making, according to Halliday (1978), is the process type employed by language users be it existential, behavioral, mental, verbal, relational or material. Such processes determine roles, assign processes, passivity and activity of the discourse participants. In this study, the analysis of these processes seeks to unravel the ideological and representational constructs embedded in the articles written about the Arab revolutions. Such a historical event provided a golden opportunity for revising western master discourse or in Said's term "Orientalist discourse" which is characterized by a set of binary oppositions, polarities and denigrating structures. The present paper is set to answer the following research questions:

1- What are the dominant process types and their frequencies in the selected articles?

2- What representational and ideological constructs do the process types embed?

3- How do the journalists build their stances towards the Arab Spring through transitivity elements?

\section{LITERATURE REVIEW}

\subsection{Halliday's systemic functional linguistics}

One of the major advances that marked the development in the twentieth century linguistics is the rise of Halliday's Systemic Functional Grammar (SFG). This new approach to language moves beyond the traditional formalist study of the set of grammatical rules to a wider functionalist and operative dimension of language within a social context. Eggins (2004, p2) maintains that "although Halliday's functional grammar deals in detail with the structural organization of English clauses, phrases and sentences." Halliday's interest has always been with the meaning of language in use in the textual processes of social life, or 'the socio-semantics of text". Meaning making for Halliday is, therefore, not an outcome of purely linguistic choices, but rather, a social process of selection, negotiation and production of those choices. In SFG, the semiotic/semantic dimension of language is prioritized and the functionality of linguistic patterns is the target of the communicative interaction in a socially contextualized setting. SFG draws on the functional trend of linguistics which emphasizes the inter-intra personal perspective of communication. Van Patten and Williams (2015, p54) contend that "Functionalist approaches to language hold that language is primarily used for communication and does not exist without language users. Functionalists view language in terms of form-to-function and function-to-form mappings." Indeed, the functional dimension has become a solid ground for language analysis in areas as Pragmatics, Sociolinguistics, Communication and Discourse Analysis. Along with the functionality in SFG, the systemization of language constitutes a focal concept in the social perspective of language use. Halliday views language as a communicative system as opposed to Chomsky's system of rules. L. Holland and M. Forbes (1993 p, 267) highlight this notion of Systemization and point out that:

The "systemic" part of systemic functional grammar involves the notion of choice within the linguistic system and provides a way of focusing on paradigmatic relations rather than the syntagmatic ones that have been the focus of syntactically oriented formal grammars. The paradigmatic axis of language is the axis from which selections are made 
by the speaker from within certain linguistic categories such as speech function (e.g., request, denial) or lexical class (e.g., noun). The syntagmatic axis of language is the axis on which language linearly unfolds in time and syntactic ordering of the above choices is achieved, with one lexical class combing with another to create meaning, for example the noun+ verb formation.

One of the central paradigmatic concepts in SFG is choice. Halliday's analysis of language as a system focuses on the choices made by language users and how these choices relate to the structural and functional levels. He stresses that "a language is a resource for making meaning, and meaning resides in systemic patterns of choice" (Halliday and Matthiessen 2004, p23). These choices serve the language user's message in terms of preferences, ideology, standpoint and many other meaningful constructs. The language user's choices between, for instance, passive and (or) active voices, noun or verb, a specific semantic field or concept instead of another reflect a large extent their purpose behind using a certain language and the interactional relation between structure and semantics. In practice, "the grammar simply stores up the choices of semantic features that are made for each semantic unit, and then generates the appropriate syntactic unit." (Fawcett 2010, p 5). Hence, in SFG as Halliday and Matthiessen (2004, p 24) explain " when we analyze a text, we show the functional organization of its structure; and we show what meaningful choices have been made, each one has seen in the context of what might have been meant but was not." At the level of realization, these choices function within two other essential conceptual dimensions, mainly stratification and metafunction. Halliday $(2014$, p24) maintains that "language is a complex semiotic system, having various levels or strata". Within SFG, language is stratified into four main strata: Context, Lexico-Gammar, Phonology-Graphology and Semantics. At the contextual stratum, attention is addressed to the Field, Tenor and the Mode which focus on what is happening, the participants and their social relations and the communicative channel (text/talk--contact/visual) respectively. As for the Lexico-grammatical stratum, the analysis covers the syntactic and lexical levels that are deployed by the language users and which reflect actor, agent, mood, theme and other aspects of the structure and vocabulary. The Phonology-Graphology stratum deals with sound system pronunciation phonemes, intonation and rhythm and word sign. The last stratum, semantics, concerns the relation between words, phrases and sentences in meaning making. Halliday divides this level into three main metafunctions, namely ideational function, interpersonal function and textual function. Each layer of these metafunctions is explained by Caffarel-Cayron (2006 p 5) in the following quote:

Thus, language constructs and is constructed by different types of meaning which the theory models as metafucntions: ideational (construing our experience of the world around us and inside us as meaning), interpersonal (enacting the world of social roles and relations as meaning) and textual (constructing ideational and interpersonal meaning as semiotic world of information organized as text in context).

Practically, each of the metafunctions is realized through linguistic means. The language user's world view and experience can be seen and lived, for instance, through transitivity lens where the types of the chosen verbs define to a considerable extent this metafunction. The social roles and relations assigned to the language user and their address 
within the interpersonal metafunction can be played using modal auxiliaries in some communicative encounters. The last metafunction, textual, which deals with the text's internal construction, can be realized through coherence mechanism and cohesive devices. (Wang 2010).

As a realization of the ideational metafunction, transitivity is one of the key concepts in SFG which enables language analysts to recognize discourse producers' covert intentions, ideological constructs and world's perception at large. For Halliday and Matthiessen (2014, p 170) "The transitivity system construes the world of experience into a manageable set of PROCESS TYPES." By process, Halliday means the type of verbs deployed by language users which can be emotional, physical, mental, static or relational. He states that "Each process type provides its own model or schema for construing a particular domain of experience as a figure of a particular kind" (ibid). The following figure summarizes the main six processes that reflect the writer's/speaker's world experience according to Halliday:

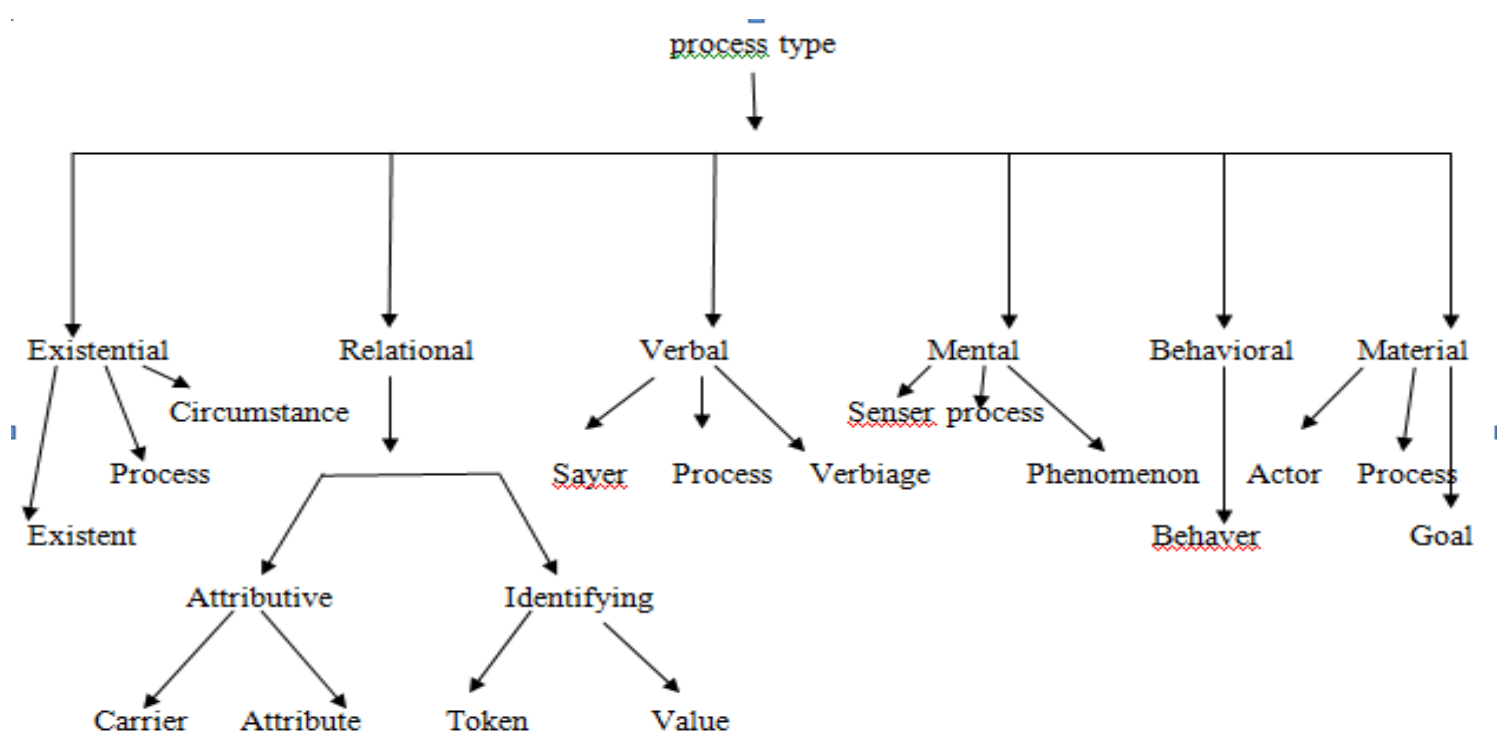

Figure (1) Transitivity represented as a system network. Adapted and modified from (Halliday 2004, p 173

Halliday goes on in his explanation and clarifies that the notion of process comprises three components that serve the system of transitivity. Halliday contends that processes "are construed as a configuration of components of three types: (i) the process itself; (ii) the participants in that process; and (iii) any circumstantial factors such as time, manner or cause." (p79). Hence, the process component is manifested in the verb phrase, the participants, who are basically actions doers or receivers, are expressed in noun phrases, and the circumstances are realized through adverbials and prepositional phrases. The following tables exemplify each process along with its constituents:

(a) Material process

\begin{tabular}{llll}
\hline Examples & Actor & Process & Goal \\
\hline - John ate a sandwich & John & Ate & A sandwich \\
\hline -The girl sewed new sockets & The girl & Sewed & New sockets \\
\hline
\end{tabular}

(b) Mental process 


\begin{tabular}{llll}
\hline Examples & Senser & Process & Phenomenon \\
\hline -He solved the equation & He & Solved & The equation \\
\hline -The students understand the lesson & The students & Understand & The lesson \\
\hline \multicolumn{1}{r}{ (c) Relational process } & & & \\
\hline Examples & Carrier & Process & Attribute \\
\hline -Andrew was smart & Andrew & Was & Smart \\
\hline -Mom is inspirational & Mom & Is & Inspirational \\
\hline
\end{tabular}

(d) Behavioral process

\begin{tabular}{lll}
\hline Examples & Bahaver & Process \\
\hline -Laura cries - & Laura & Cries \\
\hline He shouted & He & Shouted \\
\hline
\end{tabular}

(e) Verbal process

\begin{tabular}{llll}
\hline Examples & Sayer & Process & Verbiage \\
\hline -They spoke French & They & Spoke & French \\
\hline -I said no & I & Said & No \\
\hline
\end{tabular}

(f) Existential process

\begin{tabular}{llll}
\hline Examples & Process & Existent & Circumstance \\
\hline $\begin{array}{l}\text {-There was created a new barn at } \\
\text { farm }\end{array}$ & There was created & A new barn & At the farm \\
$\begin{array}{l}\text {-There existed a lot of orphans in the } \\
\text { village }\end{array}$ & There existed & A lot of orphans & At the village \\
\hline
\end{tabular}

The embedment of the worldview and/or ideology into transitivity processes and how these processes reflect the language user's covert and overt intentions is concretely revealed in the following excerpt taken from US President's Donald Trump's first speech before the UN General Assembly. The patterns of language deployed in the speech are plainly revealing of the speaker's agenda:

We will stop radical Islamic terrorism because we cannot allow it to tear up our nation and, indeed, to tear up the entire world. We must deny the terrorists safe haven, transit, funding, and any form of support for their vile and sinister ideology. We must drive them out of our nation. It is time to expose and hold responsible those countries whose support and fi - who support and finance terror groups like alQaeda, Hezbollah, the Taliban, and others that slaughter innocent people.

(UN General Assembly Speech, Sep 19, 2017, 11:40am EDT, www.cnn.com)

In the above extract, transitive verbs are essentially related to the speaker's actions and control e.g., "we will stop.... We cannot allow..... we must deny...". More than that, the use 
of modality is clearly an aiding complementary tool which expresses Trump's functional intentions in terms of future plans, prohibition and obligation. Conversely, the "terrorist" groups are ascribed objective nominal forms as passive receivers of the speaker's actions, like in "safe haven, transit, funding and any form of support". The speaker's choice of the aforementioned transitive verbs establishes some form of activity, free will and superiority of the USA, whereas the "terrorist" groups are relegated to a helpless, passive and inferior state of being. Besides, as clearly shown, the use of modality is unquestionably decisive in the construction of a discourse's foundation within a specific context. This latter is a foremost component in the communicative process as well as in the fabrication and interpretation of any type of discourse. Indeed, context, the production and interpretation of discourse make up the essence of the fields of pragmatics as a threshold to analyzing meaning making.

\section{METHODS AND MATERIALS}

The present study employs Critical Discourse Analysis which entitles a deeper examination of the ideological constructs and discursive power relations. Indeed, Halliday's Systemic Functional Linguistics is considered as the umbrella theory under which CDA flourishes as Unsworth (2000, p 275) states that "CDA and systemic functional linguistics (SFL) have been closely associated since the pioneering work of critical linguists at East Angila (Fowler et al. 1979, Fowler 1996)." Both CDA and SFL are interested in the discursive analysis of language taking into account the textual, ideational and situational dimensions; yet, a more focus of CDA on language as a social practice is to be highlighted and the impact the analyzed text is expected to have on social practices/relations is to be accentuated. Interestingly, Fairclough (1995, p 2) stresses that CDA functions within a three-dimensional framework which boils down to three types of analysis, mainly the analysis of written or spoken language, the analysis of socio-cultural discursive instances and the analysis of discourse practice. Within this framework, the present study limits itself to the textual analysis of language, more precisely transitivity analysis, from a qualitative and quantitative perspectives where the former is applied to examine the representational constructs embedded in the process types and the latter is used to identify the frequencies of these types.

The data the present paper embarks on analyzing is collected from articles written about the Arab Spring revolutions in The Washington Post, The Guardian and Le Figaro from 2010 to 2016. Given the large number of articles written during this period, resorting to simple random sampling is necessary to get a smaller representative sample of the data. According to Thyer (2010, p 42):

a simple random sample of size $\mathrm{n}$ is defined as a sample obtained in such a manner that every possible sample of size $\mathrm{n}$ has the probability of being selected. This sample is unbiased in that no population element or sample of size $n$ has a greater or lesser probability of being selected than does any other element or sample of size $n$.

Therefore, table (1) presents the number of sampled articles:

Table (1) sampled articles

\begin{tabular}{cccc}
\hline The Washington Post & The Guardian & Le Figaro & Total \\
\hline 15 & 15 & 15 & 45 \\
\hline
\end{tabular}


Transitivity analysis is applied to these articles to come up with the dominant process types, their underlying discursive power and how they help the writers build their representations of the Arab Revolutions.

\section{DATA ANALYSIS AND DISCUSSION}

The analysis of the transitivity system has uncovered interesting facts about the articles' view and representation of the Arab Spring. The employment of certain process types more than others, assigning roles to participants and identification of specific circumstantial constituents reflect the writers' ideological constructs and the newspapers' line of argumentation. Data analysis of transitivity has brought about the dominant process types, their frequencies and interpretation. The below graphs represent these process types and their frequencies:

Figure (2) process types and their distribution in Le Figaro

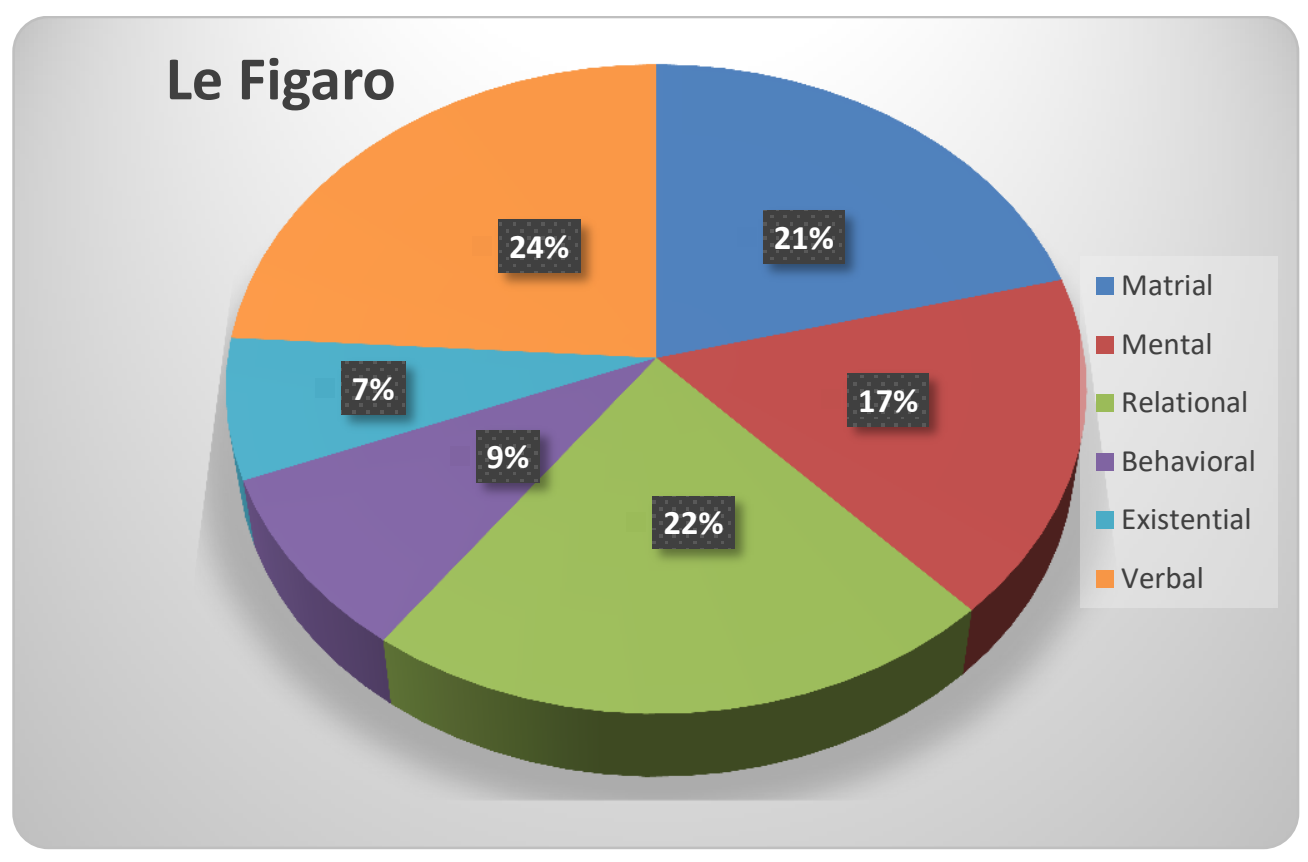

Figure (3) process types and their distribution in The Washington Post

\section{The Washington Post}


Figure (4) process types and their distribution in The Guardian

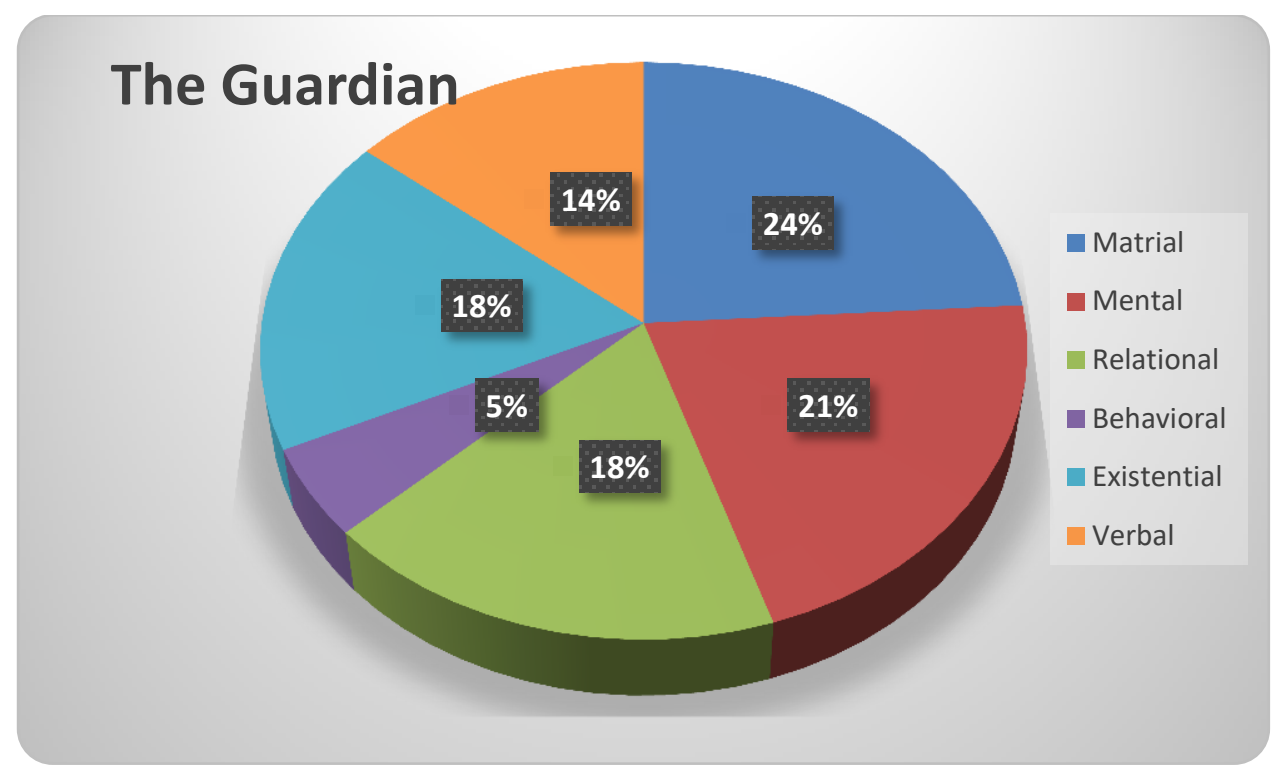

There is some kind of convergence in the results and their distribution across the three newspapers' articles. The interpretation of the processes and their frequencies can be read as follows: the relative rise in material processes has to do with the abundance of actions and interplaying actors. The mental processes occupy a reasonable position through which the writers express their stances, assess events and probe into the protestors' and rulers' cognitive structure. Frequently used, relational processes are noticeably deployed to identify and define the relationship among the different actors. Behavioral and existential processes seem to be less resorted to by writers and are overshadowed by other processes. As for verbal processes, their presence is fairly detectable and their use is usually associated with citing witnesses and authorities.

The analysis of these processes has helped reveal significant findings. It seems that the journalists of the three newspapers tend to associate these verb processes with certain actors/doers more than others; a choice which helps consolidate their line of argumentation and ideological stance. Table (2) shows the process types and their corresponding actors/doers:

Table (2) process types and their corresponding actors

\begin{tabular}{cll}
\hline & \multicolumn{1}{c}{ Process Type } \\
\hline \multirow{4}{*}{ Material } & - Revolt / Demonstrate (demonstrators) \\
& - Torture (regimes / dictator) \\
& -Help (West-US) \\
& -Attack (demonstrators/police) \\
& -Give (regimes / west) \\
\hline Mental & - Think / know / believe (presidents / cited authorities) \\
\hline Relational & - To be (demonstrators / The West ) \\
\hline \multirow{3}{*}{ Behavioral } & -Have (Arab Countries vs their people / West vs East ) \\
\hline Existential & -Cry (demonstrators) \\
\hline & -Kill (regimes) \\
\hline Verbal & -There is... (change / dictatorship) \\
\hline & -Tell/ say (quoted authorities/Presidents/ rebels) \\
\hline
\end{tabular}


The analysis and interpretation of each process is presented from exemplary extracts of each newspaper.

\section{Le Figaro}

Material

\section{Extract 1}

\begin{tabular}{llll}
\multicolumn{1}{c}{ Actor } & Process & Circumstance (destination) & \multicolumn{1}{c}{ Goal } \\
\hline $\begin{array}{l}\text { Une multitude de } \\
\text { refugies syriens }\end{array}$ & fuient & En direction du nord & $\begin{array}{l}\text { Les bombes du régime } \\
\text { et de Moscou }\end{array}$ \\
\hline
\end{tabular}

English Translation

\begin{tabular}{llll}
\multicolumn{1}{c}{ Actor } & Process & Circumstance (destination) & \multicolumn{1}{c}{ Goal } \\
\hline $\begin{array}{l}\text { A multitude of Syrian } \\
\text { refugees }\end{array}$ & Flee & northbound & $\begin{array}{l}\text { the bombs of the } \\
\text { regime and Moscow }\end{array}$ \\
\hline
\end{tabular}

This extract reflects the actor's reaction towards the goal. Using the process flee, the writer tries to draw a vivid picture of what the actor is facing and doing. The use of the intensifying quantifier A multitude of with the head actor Syrian refugees creates a picture of crowds, which have been left with no other choice, running away from the goal's destructive acts. Also, the circumstance northbound is used to valorize the region and, hence, the deeds of the Syrian free army. This material process is indeed a representative sample of similar processes which describe the actions taken or inflicted upon the actors which represent the rebels and how they affect the events on the ground.

Mental

Extract 2

\begin{tabular}{lll}
\hline \multicolumn{1}{c}{ Actor } & \multicolumn{1}{c}{ Process } & \multicolumn{1}{c}{ Circumstance } \\
\hline $\begin{array}{l}\text { les gouvernements français et } \\
\text { americain }\end{array}$ & Savant & qu'il n'est jamais bon de commencer une guerre \\
en année d'élection présidentielle
\end{tabular}

English Translation

\begin{tabular}{lll}
\multicolumn{1}{c}{ Actor } & \multicolumn{1}{c}{ Process } & \multicolumn{1}{c}{ Circumstance } \\
\hline $\begin{array}{l}\text { the French and } \\
\text { American governments }\end{array}$ & Know & that it is never good to start a war in a \\
presidential election year.
\end{tabular}

The process 'know' reveals the actor's understanding and, then, reaction towards the Syrian situation. This reaction does not stem from a moral obligation towards saving innocent civilian lives rather from a domestic need for avoiding a war which may have damaging 
presidential consequences. Hence, this extract proves that some western countries preach what they do not do and strips them of the aura of morality and justice they try to round themselves by at the level of international relations.

Relational

Extract 3

\begin{tabular}{lccc}
\hline \multicolumn{1}{c}{ Carrier } & & Process & Attribute \\
\hline Le Yemen & Est & & le maillon faible qui hante le monde Arab. \\
\hline
\end{tabular}

\section{English Translation}

\begin{tabular}{llll}
\hline \multicolumn{2}{l}{ Carrier } & Process & Attribute \\
\hline Yemen & Is & The weak link that haunts the Arab world \\
\hline
\end{tabular}

The carrier Yemen is attributed a low status in the Arab world stability chain. The relational process is enhances the relation between the Carrier and the state of instability, and the lexical item haunts extends this relationship of the carrier with the Arab world. This latter is haunted and looks like having nightmares about the fragile case of Yemen which is fractioned by tribalism, stinging by corruption and hijacked by Al Qaeda. Indeed, the Yemeni case is quite similar to the Libyan one but its geographic adjacency and tribal affinity, the Houthis, with Iran make it far from a soon stability.

Behavioral

\section{Extract 4}

\begin{tabular}{lcc}
\hline \multicolumn{1}{c}{ Behaver } & Process & Circumstance \\
\hline $\begin{array}{l}\text { Le régime, rebelles, Kurdes et } \\
\text { djihadistes }\end{array}$ & S'affrontent & Sur un territoire de plus en plus morcelé. \\
\hline
\end{tabular}

\section{English Translation}

Behaver Process Circumstance (place-manner)
The regime, rebels, Kurds and Clash in a territory more and more fragmented.
jihadists
The extract above exposes the kind of dominant actors and their actions on the Syrian
ground. The behaver encompasses confronting forces and is used with a process that best
mirrors its behavior. The process clash not only defines the behaver's action, but also evokes
the repercussions of these actions on the country. This repercussion is manifested in the
circumstance which stands for place and manner and is fragmented by the behaver.


Existential

Extract 5

\begin{tabular}{ccc}
\hline Existent & Process & Circumstance \\
\hline $69,3 \%$ des Syriens & Vivent & En extreme poauvrete \\
\hline
\end{tabular}

English Translation

\begin{tabular}{|c|c|c|}
\hline Existent & Process & Circumstance \\
\hline $69,3 \%$ of Syrians & Live & In extreme poverty \\
\hline
\end{tabular}

The existing reality of a large portion of the Syrian people during the Arab Spring is discussed in the above extract. The writer employs the process live to introduce a fact and describe a process of enduring and experiencing of the circumstance poverty. More than two thirds of the Syrian populations endure tough circumstances which seem to aggravate ever since they stood up against the regime in the early days of the revolution.

Verbal

\section{Extract 6}

\begin{tabular}{|c|c|c|}
\hline Sayer & Process & Verbiage \\
\hline Son president & Dit & $\begin{array}{l}\text { vouloir reformer } \mathrm{L} \text { 'islam et protéger ses } \\
\text { coptes. }\end{array}$ \\
\hline
\end{tabular}

English Translation

\begin{tabular}{|c|c|c|}
\hline Sayer & Process & Verbiage \\
\hline Its president & said & $\begin{array}{l}\text { he wanted to reform Islam and protect } \\
\text { his Copts. }\end{array}$ \\
\hline
\end{tabular}

This extract is about one of Egypt's President Sissi's several declarations after winning the presidential elections. The sayer, its president, verbalizes some promises to his addressees, the Egyptian people, which remain less powerful than behavioral or material processes. In reality, putting this extract in the indirect speech lessens the intensity of the verbiage and gives the writer distance from what the sayer has to say. The verbiage in this extract presupposes that the Copts are threatened perhaps by an Islam that has to be reformed. This reform is undertaken by the president who is presented here as a guardian of "his Copts". 


\section{The Washington Post}

Material

\section{Extract 7}

\begin{tabular}{ccc}
\hline \multicolumn{1}{c}{ Actor } & Process & Circumstance \\
\hline majority-Shiite population & Revolted & during the Arab Spring \\
\hline
\end{tabular}

In this extract, the writer addresses the stance of the Shiite population from the revolution in Bahrain. The actor, majority-Shiite population, is semantically loaded and it denotes that minority-Sunni population has more power. This actor is paired with the process revolted to show the sort of action it takes, which is revolting and rising up. The process revolted connotes rising up against a situation of injustice and inequality imposed by the ruling class. The circumstance during the Arab Spring associates the revolts with the wave of revolutions across the Arab world and, hence, places Bahraini regime within a similar atmosphere of congestion that other Arab regimes are enduring. This material process extract is a prototype of the actions taken by the actors, mostly demonstrators, in other revolting Arab countries, and how they affect the course of actions of the Arab Spring.

Mental

\section{Extract 8}

\begin{tabular}{lccccl}
\hline Sensor & Process & \multicolumn{1}{c}{ Actor } & Process & $\begin{array}{c}\text { Circumstance } \\
\text { (manner) }\end{array}$ & $\begin{array}{l}\text { Circumstance (behalf) } \\
\text { I }\end{array}$ Think \\
& $\begin{array}{l}\text { the period } \\
\text { between now } \\
\text { and then }\end{array}$ & Will be & quite rocky & $\begin{array}{l}\text { for the Egyptian people, } \\
\text { for the region, and for } \\
\text { us. }\end{array}$ \\
\end{tabular}

The above extract reveals the cognitive state of mind of Hillary Clinton about the Arab Spring's events. The sensor here, Hillary Clinton, uses one of cognition verbs, think, to express her, as well as the U.S.A.'s stand point toward the revolutions. The second process, will be, is a temporal reference to the repercussion of the previous actor which is followed by a circumstance of manner to describe the physical impact of the revolutions and a behalf circumstance to indicate the receiver of the impact. Mental processes help probe into the sensor's perceptional and cognitive inner world and understand how they perceive and, hence, react to things.

Relational

\section{Extract 9}

\section{Carrier}

Erdogan and Abdel Fatah al-Sissi, Egypt's general-turned-president

\section{Process}

have

become

\section{Attribute}

certifiably paranoid in their views of the United States 
Relational processes identify the relation between two entities. Instead of an actor, relational processes take a carrier which refers to the bearer of the action. The carrier in this extract, presidents Erdogan and al-Sissi, is linked to the attribute with a process of change and development, have become. This change or even transformation of the carrier towards the attribute is characterized by a pejorative description of this relational state. The biding relation between the two presidents and the U.S.A. is built upon power struggle and asymmetry where the latter forms a sort of threat to the formers.

Behavioral

Extract 10

\section{Behaver}

The Mubarak regime

\section{Process}

is coming back to power

Behavioral processes are situated between mental and material ones. They often describe an activity in which the mental and physical facets come to play together and are usually intransitive. The behaver in the above extract is the Mubarak regime and it is behaving towards a return to power which is reflected in the continuous form of the process $i s$ coming. Through this extract, the writer depicts one of the dominant forms of behavioral relations governing the Arab Spring's actions where most of the regimes fought back and adopted a unanimous aggressive inclination towards hanging on to power.

Existential

Extract 11

\begin{tabular}{|c|c|}
\hline Process & Existent \\
\hline There is & no path of democracy \\
\hline
\end{tabular}

Existential processes are deployed to delineate the existence or happening of something. They use the verbs to be and exist followed by a noun phrase. The use of the existential process there is is meant to describe, in the writer's opinion, a gloomy reality of the absence of a genuine path to democracy. This absence is the result of the dominance of chaos and retaliation on the part of the toppled dictators.

Verbal

Extract 12

\begin{tabular}{|c|c|c|c|}
\hline Sayer & Process & Verbiage & Circumstance \\
\hline $\mathrm{He}$ & Demands & Change & in Bahrain. \\
\hline
\end{tabular}


Verbal processes represent the sayer's proposition, which is called verbiage here, communicated to a certain addressee. The sayer in the above extract is the former President Obama who employs a semantically loaded process demands. This process places the sayer in a stronger communicative position vis a vis a general addressee who is supposed to fulfill the verbiage change. This verbal process has a semantic dimension of commands and locks the sayer and addressee, Bahraini regime and people, in a relation of order-obedience that the West has constructed with the East ever since colonialism and seems to revitalize during the Arab Spring.

\section{The Guardian}

Material

Extract 13

\begin{tabular}{llll}
\hline \multicolumn{1}{c}{ Actor } & Process & \multicolumn{1}{c}{ Circumstance (what and where) } & \multicolumn{1}{c}{ Circumstance (purpose) } \\
\hline $\begin{array}{l}\text { the United States } \\
\text { and the west }\end{array}$ & will pour & $\begin{array}{l}\text { in support of Egypt, } \\
\text { billions of dollars into the Middle } \\
\text { East }\end{array}$ & $\begin{array}{l}\text { Tunisia and other } \\
\text { countries embracing } \\
\text { democracy }\end{array}$ \\
\hline
\end{tabular}

The United States and the West are the essential actors in this extract and the main players which are taking actions towards some of the Middle Eastern countries. The material process will pour indicates the bestowal of one party on a needy other with abundance. The circumstances above reveal the process's realization in terms of what, where and why. Therefore, the actor is held in an upper powerful status with its manipulation of Arab countries through financial means and reinforces the orient's dependency on the occident.

Mental

Extract 14

\begin{tabular}{|c|c|c|c|}
\hline Senser & Process & Actor & Process \\
\hline Some Islamists & Believe & Elections & Are forbidden \\
\hline
\end{tabular}

The writer's delving into the Islamists' mentality is realized through the process believe. The senser's belief in the legitimacy of the actor, elections, is religiously oriented. This actor is judged by a passivised process in which the agent is omitted to foreground the act of forbidding and perhaps hide the forbidder, in this case God. Obviously, through this extract the writer criticizes the Islamists' mindset and stance towards the process of elections and questions their willingness to be real partners in the rebuilding of the post revolution political process. 
Relational

Extract 15

\begin{tabular}{|c|c|c|}
\hline Possessor & Process & Possession \\
\hline the despots & Have & more gravitas \\
\hline
\end{tabular}

In his account of the relational process between the toppled despots and their people, the writer believes that these despots still hold some reverence from the part of their people or at least some of them. The possessive process have defines the possessor's quality, more gravitas, which empowers its position vis a vis the governed people. These latters seem to still hold their despotic rulers in high esteem and not only openly endorse them, but even fight with them in an attempt to regain power.

Behavioral

Extract 16

\begin{tabular}{llll}
\hline \multicolumn{1}{c}{$\begin{array}{c}\text { Circumstance } \\
\text { (temporal) }\end{array}$} & \multicolumn{1}{c}{ Behayer } & \multicolumn{1}{c}{ Process } & \multicolumn{1}{c}{$\begin{array}{c}\text { Circumstance } \\
\text { (recipient) }\end{array}$} \\
\hline $\begin{array}{l}\text { For more than two } \\
\text { months now }\end{array}$ & $\begin{array}{l}\text { Syrian security } \\
\text { forces }\end{array}$ & $\begin{array}{l}\text { have been killing and } \\
\text { torturing }\end{array}$ & their own people \\
\hline
\end{tabular}

The extract above describes one of the despicable and recurring behaviors of the Syrian regime. The writer puts the process in the present perfect continuous to emphasize the length, the extent and gravity of the behaver's recurrent acts of killing and torture. The temporal and recipient circumstances are deployed to frame the process where the former highlights the duration of the process and the latter defines the receiver of the behaver's deeds. This behavioral process has characterized the acts of most of security and military forces towards the demonstrators across the revolting countries and has also been a common process committed by the falling despots.

Existential

Extract 17

\begin{tabular}{llll} 
Existential & Existent & Circumstance (place) & \multicolumn{1}{c}{ Circumstance (purpose) } \\
\hline There is & an opportunity & in that region & $\begin{array}{l}\text { to focus on advancing our values } \\
\text { and enhancing our security. }\end{array}$ \\
\hline
\end{tabular}

From an optimistic perspective, the writer believes in the existence of a chance for the West during the revolutions to advance its values and foster its security. The existent here opportunity reflects the existence of a plausible room and high possibility for intervening. This existing reality remains a hope to influence the "place circumstance", the region, with 
advancing values and enhancing security. Indeed, the seizure of such opportunities is a dominant act through which western powers endeavor to root their ideologies and secure their interests during the uprisings.

Verbal

Extract 18

\begin{tabular}{|c|c|c|}
\hline Sayer & Process & Verbiage \\
\hline One detainee & Said & security forces had executed 26 detainees \\
\hline
\end{tabular}

Quoting the declaration of one of the Syrian detainees, the writer uses the verbal process said to create a verbalizing depiction of the atrocities of the Syrian regime. Also, this process indicates the attainment of first-hand information from a sayer who has lived the experience of verbiage. Using verbal processes entitle writers to bring the reader closer to given propositions and sometimes distance themselves from them in order not to fall in the trap of subjectivity.

\section{CONCLUSION}

The data analysis has revealed an interesting reliance on all types of processes by the articles' writers in building their representation of the Arab revolutions. Another significant finding from data analysis is the distribution of these types, and the actors and agents they occur with. The analysis of transitivity processes allows close scrutiny of the types of verbs, actors and circumstances the writer opts for and, hence, the ideology they disseminate. The deployment of transitivity analysis elements is manipulated by the writer's purpose behind the proposition through which they assign roles, define positions and steer the aim of the argument. Such analysis is expected to help the reader decode and decipher the hidden structures and biases embedded in the discourse manipulator. Consequently, the reader engages in an internal negotiation with the text constituents and develops effective critical reading and immunity against what might seem at first "innocent use of language".

\section{REFERENCES}

Caffarel, A. (2006). A Systemic Functional Grammar of French: From Grammar to Discourse. London: Continuum.

Eggins, S. (2004). An Introduction to Systemic Functional Linguistics: 2nd edition. London: Continuum.

Fairclough, N. (1995). Critical Discourse Analysis: the Critical Study of Language. London: Routledge.

Fairclough, N. (2010). Analysing Discourse Textual Analysis for Social Research. London:

Routledge

Fawcett, R. P. (2010). A Theory of Syntax for Systemic Functional Linguistics. Amsterdam: John Benjamins.

Fowler, R.(1991). Language in the News: Discourse and Ideology in the Press. London and New York : Routledge. 
Gelvin, J. L. (2015). The Arab Uprisings: What Everyone Needs to know. Oxford: Oxford University Press.

Halliday, M. A. (1978). Language as a Social Semiotic: The Social Interpretation of Language and meaning. Baltimore: Edward Arnold.

Halliday, M. A. K., \& Matthiessen, C. (2004). An Introduction to Functional Grammar. London: Hodder Education

Holland, A. L., \& Forbes, M. M. (1993). Aphasia Treatment: World Perspectives. London: Chapman \& Hall

Ramadan, T. (2012). Islam and the Arab Awakening. New York, NY: Oxford University Press.

Thyer, B. (2010). The Handbook of Social Work Research Methods. Thousand Oaks, CA: Sage Publications.

Unsworth, L. (2006). Researching Language in Schools and Communities Functional Linguistic Perspectives. London: Cassell.

Van Dijk, T.A.(1985). Handbook of Discourse Analysis.vol 3. London: Academic Press.

Van Dijk, T.A.(1995). Discourse Semantics and Ideology. Discourse and Society. 6 (2): 243-

VanPatten, B, Williams, J, (2015).Theories in Second Language Acquisition: an Introduction. London: Routledge.

Wang, K., and H.Qin.(2010).A Parallel Corpus-based Study of Translational Chinese. In Using Corpora in Contrastive and Translation Studies, ed. R.Xiao. 164-181. Newcastle: Cabridge Scholar Publishing.

Wodak, R., \& Meyer, M. (2016). Methods of Critical Discourse Analysis. Los Angeles: Sage.

\section{AUTHORS'BIO}

Aymane Edouihri is Ph.D student at Sidi Mohamed Ben abdllah faculty of Arts and Humanities Fes, Morocco. He got his BA from the faculty of Arts and Humanities Ibn Tofail, Kenitra. He is a high school English teacher. He got his Masters degree in linguistic and Literary Studies Ain Chok Casablanca. He participated in the international conference on Identity in the 21st Century: New Realities New Challenges in 2017 as well as in the international conference on diaspora at Sidi Mohamed Ben Abdlah university in 2019.

Dr. Yahya Yachouti is professor of English at Sidi Mohamed Ben Abdllah university Fes, Morocco. He is Vice-Director (and one of the founders) of the Research Lab : Discourse, Creativity and Society: Perception and Implications." (Discreso) Founder and Coordinator of the Research Group: Space, Culture and Globalization. Dr. Yachouti is a specialist of Afro-American gender studies and post-colonial studies. 